\title{
Kontraktuele geregtigheid, goeie trou en die optrede van 'n kurator met betrekking tot onuitgevoerde kontrakte in die insolvensiereg
}

\author{
A.L. Stander \\ Departement Handelsreg \\ Potchefstroomse Universiteit vir $\mathrm{CHO}$ \\ POTCHEFSTROOM
}

\begin{abstract}
Contractual justice, good faith and the conduct of a trustee in relation to unexecuted contracts in the law of insolvency

Regarding unexecuted contracts and the important role they play in the law of insolvency, it is necessary to establish why a trustee is permitted 10 become a party to the contract between the insolvent and the third party without either party's consent. This procedure mainly concerns the principle of public policy as expressed in terms of good faith. Due to public policy and good faith, it is further necessary to create a healthy balance between the principles underlying the enforcement of contracts and those underlying the equal treatment of creditors of the estate. To my mind the contracting third party can enforce the contract when its execution has reached the stage where the position of the concursus creditorum will not be affected. It is concluded that this stage is reached when no further performance is required of the insolvent estate. Under these circumstances it should be explicitly acknowledged that, on the basis of good faith, the third party has the right to insist on the performance of the contract. It is also essential that the decision of the trustee to enforce or to terminate the contract must be measured by the principle of good faith.
\end{abstract}

\section{Inleiding}

Wat 'n mens dadelik by die bestudering van onuitgevoerde kontrakte in die insolvensiereg opval, is die negering van die werklike aard van die verhouding tussen kontrakpartye. Wanneer 'n kontrak gesluit word, kry ons sekere persone wat op 'n besondere wyse en soms met groot koste en moeite vir hulle sekere voorregte, regte en verpligtinge beding het. Daar bestaan 'n besondere verhouding tussen hierdie partye tot die uitsluiting van ander. Met sekwestrasie verander hierdie verhouding totaal. 'n Buitestaander (in die persoon van die kurator of voorlopige kurator) tree na vore, maak as't ware die kontrak oop en tree dan namens en ten behoewe van vele ander betrokkenes op, naamlik al die skuldeisers van die insolvente boedel - al is dit teen die sin of ten koste van die 
Kontraktuele geregtigheid, goeie trou en die optrede van '" kurator ...

ander party. Onmiddellik geniet die groep skuldeisers se belange voorkeur bo dié van die "onskuldige" kontrakparty sonder dat hy enige sê in die saak het.

Die vraag is vervolgens hoe hierdie situasie met verwysing na die beginsel van bemoeiingsvryheid ${ }^{1}$ (as onderdeel van kontrakteervryheid) verantwoord word. Die vraag is verder ook hoe dié situasie met verwysing na die beginsel van die afdwingbaarheid van kontrakte verantwoord word, want daar bestaan geen twyfel nie dat as die onskuldige party sy sin sou kry, hy bo ander skuldeisers van die insolvente boedel bevoordeel sal word - skuldeisers wat in presies dieselfde posisie as hyself verkeer. Hoewel dit ten alle koste verhoed moet word, blyk dit in stryd te wees met die klassieke kontrakteregteorie. Laasgenoemde hou in dat dit juridies-eties aanvaarbaar is dat die partye gebonde gehou moet word aan dit waaroor hulle ná onderhandeling wilsooreenstemming bereik het. Dit veronderstel dat daar wel oor die kontraksluiting en oor die kontrakbedinge onderhandel is of kon word (Van der Walt, 1989:85). Verder hou die kontrakteregteorie in dat aan die redelike verwagting wat die partye ten opsigte van die kontrak koester, uiting gegee en dit beskerm moet word. Hierdie uitgangspunt is in pas met die vertrouensteorie wat by die vasstel van kontraktuele gebondenheid gebruik word. So verklaar Eiselen (1988:83) dat die kontrak 'n produk van die wilsooreenstemming tussen die partye is en dat daardie wilsooreenstemming te vinde is in die redelike vertroue wat oor en weer tussen die partye tot stand gebring is.

Gedagtig hieraan kan met reg gevra word of, en indien wel hoe, dit moontlik is dat die kurator ' $n$ keuse kan uitoefen om die betrokke onuitgevoerde kontrak na te kom of spesifieke nakoming te weier, en daardeur die kontrak in werklikheid effektief te beëindig. Wat baie duidelik is, is dat in die geval van die insolvensiereg van die bestaande kontrakregtelike beginsels afgewyk móét word. Dit is eenvoudig onmoontlik om ná sekwestrasie aan elke skuldeiser presies dit te gee waarvoor hy gekontrakteer het. Die insolvent se laste oorskry sy bates. Watter riglyne kan derhalwe oorweeg word om behoorlike beregtiging van skuldeisers inter se te bewerkstellig? In hierdie artikel sal gepoog word om aan te dui dat dit 'n vraag is wat (wat die insolvensiereg betref) aan die hand van geregtigheidsoorwegings en die vereiste van goeie trou bepaal moet word. Binne 'n reformatoriese regsteorie word billikheid en goeie trou as beginsels van juridiese moraal beskou. Hierdie beginsels is regulatief van aard (Van Eikema Hommes, 1972:481-546).

$1 \quad$ Kyk par. 2.4 vir 'n bespreking van hicrdic begrip 


\section{Die beginsels van die klassieke kontrakteregteorie}

Die Suid-Afrikaanse klassieke kontrakteregteorie word gekenınerk deur veral die beginsels van kontrakteervryheid, afdwingbaarheid ${ }^{2}$ en konsensus. Die beginsel van konsensus ${ }^{3}$ beteken dat die kontrak deur die blote wilsooreenstemming van die partye tot stand gebring word. Geen formaliteite hoef nagekom te word nie. Die beginsel van afdwingbaarheid kom daarop neer dat die partye aan hul kontrak gebonde is. Die beginsel van kontrakteervryheid hou in dat enige persoon 'n kontrak kan sluit wanneer hy wil, met wie hy wil en met welke inhoud hy wil. Kontrakvryheid kan vyf verskillende betekenisse hê:

\section{- Formele kontrakteervryheid}

Formele kontrakteervryheid (vormvryheid) beteken dat daar in beginsel geen formaliteite vir die totstandkoming van 'n kontrak vereis word nie. Blote wilsooreenstemming is voldoende (Feenstra \& Ahsmann, 1980:5).

\section{- Vergestaltingsvryheid}

Vergestaltingsvryheid hou in dat die partye enige geoorloofde inhoud aan hul kontrak kan gee en dat die partye die reëlende reg kan wysig om by hul behoeftes aan te pas.

\section{- Sluitingsvryheid}

Sluitingsvryheid beteken dat 'n mens in beginsel vry is om te besluit of en indien wel, met wie hy wil kontrakteer.

\section{- Bemoeiingsvryheid}

Bemoeiingsvryheid hou in dat daar nie ex post facto met 'n kontraktuele verhouding ingemeng behoort te word nie. Die kontrak behoort afgedwing te word soos die partye ooreengekom het. "Afspraken, hoezeer zij ook naakt zijn, moeten worden nagekomen" (Feenstra \& Ahsmann, 1980:6). Pacta sunt servanda is die sinoniem vir kontrakteervryheid in hierdie sin (Eiselen, 1988:11).

2 Afdwingbarheid kom na vore in dic spreuk pacia sunt servanda. In die geval van skriftelike kontrakte vind dit neerslag in talle reels, soos dic integrasıerecl en uitlegtegnieke - veral die recl teen ckstrinsicke getuienis. Algemeen is dit belangrik dat kontrakte ter wille van regsekerheid afgedwing word. Dic rol wat kontrakte in die regs- en handelsverkeer speel, lei derhalwe daartoc dat regsekerheid en die behoefte daaraan 'n sentrale plek by die beginsel van afdwingbaarheid van kontraktc innecm

Onderskeidelik gemotiveer deur dic wilsbenadering staan dit ook as kontrakvormvryheid bekend 
Kontraktuele geregtigheid, goeie trou en die optrede van 'n kurator...

- Kontrakteervryheid

Kontrakteervryheid in omvattende sin dui op die onwenslikheid dat die owerheid enigsins die ander vorme van kontrakteervryheid aan bande lê. Aan hierdie beginsels en vereistes moet in die moderne handelsverkeer uitvoering gegee word (Van der Walt, 1989:82). Kontrakteervryheid verteenwoordig uitgangspunte wat in die openbare belang geld en word beliggaam in die goeie-trou-vereiste van die kontraktereg. Dit bepaal die grense waarbinne toegelaat kan word dat partye hul kontrakteervryheid uitoefen. Dié beginsels vorm derhalwe die basis van die SuidAfrikaanse kontraktereg, waaraan ter wille van kontraktuele billikheid, algemene geregtigheid en regsekerheid voldoen moet word. Sinvolle handels- en regsekerheid kan alleen bereik word as bogenoemde beginsels vir albei kontrakpartye gelykelik bestaan. In die geval van sekwestrasie van die boedel van een van die kontrakpartye, wil dit egter voorkon of hierdie beginsels ${ }^{4}$ met die toetrede van die kurator vervaag en op die agtergrond geskuif word. Die onderhawige ondersoek het derhalwe te make met die vraag of daar perke aan bemoeiingsvryheid gestel kan word en indien wel, die norm waardeur bepaal word welke perke gestel kan word om as grondslag vir die inmenging van die kurator 5 te dien. Die vraag is of die openbare belang (soos dit in die vereiste van goeie trou tot uiting kom) nie juis die regverdiging vir die reël in die geval van onuitgevoerde kontrakte is nie. Dui dit nie juis aan dat die negentiende-eeuse kontrakteervryheidsgedagte (met sy afdwingbaarleeidspostulaat) in die geval van insolvensie deur die beëindigingskompetensie van die kurator getemper word omdat die goeie trou dit vereis nie? Of is hier, in die geval van die sekwestrasie van een van die partye se boedels, ' $n$ anomalie ${ }^{6}$ ter sprake, sodat 'n selfstandige beginsel as norm geformuleer en erken moet word? Die antwoord wat op hierdie vrae aangebied word, moet 'n regsetiese grondslag hê. Dit is na my mening 'n voorvereiste waaraan die gestelde beginsel onderhewig is.

\section{Die kontrakteervryheidsgedagte}

Die kritieke vraag is vervolgens hoe dit moontlik is dat die kurator met die kontraktuele verhouding van die insolvent en sy teenparty kan inmeng deur uitvoering daarvan effektief te mag beëindig. ${ }^{7}$ Pacta sunt servanda word vandag meesal gebruik om die absolute afdwingbare karakter van kontraktuele

Hier word veral verwys na afdwingbaarheid en bemociingsvryheid as onderskeibare betekenisse van dic beginsel van kontraktecruryhcid

5 Hier word verwys na dic kompetensic van die kurator om in onuitgevoerde kontrak na te kom of spesifieke nakoming te weicr, en daardeur dic kontrak in werklikheid effekticf te becindig

6 Te wyte aan dic besondere (insolvente) omstandighede van cen van dic kontrakpartyc.

7 Dit is duidelik 'n ingreep op die partye se kompetensic om hul eic sake te reel 
verhoudinge aan te dui (Eiselen, 1988:56). Regsgeleerdes erken wel dat sekere perke aan die vergestaltingsvryheid en benoeiingsvryheid gestel moet word om die openbare belang te beskerm. Die grense van hierdie uitsondering is egter baie eng en strek kwalik wyer as die bedinge wat die handelsvryheid beperk, kontrakte wat immoreel is, weddenskapskontrakte en kontrakte wat onwettig is (De Wet \& Van Wyk, 1992:89 e.v.; Kerr, 1989:98 e.v.). Steeds raak hierdie genoemde uitsonderings nie die vraag na die grondslag vir die inmenging van die kurator van 'n gesekwestreerde boedel en die feit dat die ander kontrakparty nie die spesifieke nakoming van die onuitgevoerde kontrak kan eis nie. Dit is ook gevestigde reg dat die blote feit dat 'n kontrak of beding onbillik is, nie voldoende is on dit onafdwingbaar te maak nie (Wells v SA Alumenite Co 1927 AD 6972 e.v. $)^{8}$

In die klassieke Romeinse reg was afsprake wat nie aan die gestelde formaliteite voldoen het nie, nie afdwingbaar nie. Met die resepsie van die Romeinse reg gedurende die Middeleeue is hierdie reel behou (Feenstra \& Ahsmann, 1980:13). Gedurende dieselfde tyd het die Romeinse reg egter gaandeweg verandering ondergaan. Consensus het die grondslag vir kontraktuele gebondenheid gevorm, in teenstelling met die stelsel waar die grondslag in die vorm van die regshandeling geleë was. Dit is in hierdie verband dat pacta sunt servanda 9 oorspronklik die betekenis gehad het dat 'n kontrak afdwingbaar was indien albei partye vryelik daartoe toegestem het, ongeag die vorm waarin dit gegiet is (Visser, 1984:646; Feenstra \& Ahsmann, 1980:6-7; Eiselen, 1988:56 e.v.). Gedurende die Renaissance het ' $n$ belangrike klemverskuiwing 10 ten aansien van die betekenis van die uitdrukking plaasgevind. Daar is van die standpunt uitgegaan dat elke mens sekere fundamentele regte het en dat hy outonoom is (Eiselen, 1988:57); gevolglik kan hy ook vryelik ooreenkomste aangaan. De Groot het die wil om aan ' $n$ ander ' $n$ reg te verskaf as die grondslag van kontraktuele gebondenheid aangemerk. 11 'n Verdere vereiste wat deur hom gestel is, is dat die wilsuiting vryelik moes geskied het (De Groot, 1664:3.1.103.1.11; kyk in die algemeen ook Van Apeldoorn \& Fockema Andreae, 1939). In daardie geval is 'n persoon dan verplig om sy belofte na te kom. Waar pacta sunt

Vergelyk ook 1942 Marlin v Durban Turf Club and others AD 112131 waarin beslis word dat "one of the requirements of public policy is that partics who have freely entered into an agrecment should, in the absence of frand, be held to it" (my kursivering - ALS).

9 Dic beginsel het sy oorsprong in dic Kanonicke reg gehad (Feenstra \& Ahsmann, 1980:6, 12 "Allc afspraken mocten worden nagekomen"; vgl. ook Eisclen, 1988:56).

10 Dit het onder invloed van die sterkerwordende natuurregleer (en veral die Rasionalisme) en 'n stcrk filosoficsc gerigtheid plaasgevind (kyk Eisclen, 1988:57 c.v)

11 Consensus het met ander woorde dic grondslag van kontraktuele gebondenheid geword. 
servanda dus oorspronklik gebruik is om die beginsel van konsensus deur te voer, 12 het De Groot die klem op die bindende krag van 'n ernstige belofte geplaas - dit is volgens hom 'n gebod van die natuurreg dat ooreenkomste wat vrywillig aangegaan is, nagekom moet word (Feenstra \& Ahsmann, 1980:18-19). Die mens is ' $n$ vrye, outonome en rasionele wese, wat heerskappy oor sy goed en oor homself voer; daarom is hy volgens De Groot in staat om daarmee te handel volgens sy eie goeddunke en behoort die reg daaraan gevolg te gee (De Groot, $1664: 3.1 .12$ ).

Tog is die beginsel van pacta sunt servanda nie as absoluut gesien nie, aangesien die vrye wilsuitoefening van die mens van regsweë aan bande gelê kon word:

Hij (De Groot) wijst er met name op dat het positieve recht beperkingen heeft aangebracht op het beginsel van de vrijheid om zich zodanig te binden dat een ander een recht verkrijgt ... Deze kunnen niet alleen daarin liggen dat toezeggingen met een bepaalde inhoud ongeldig worden verklaard ... maar ook in de wijze waarop men zich door toezegging kan verbinden (Feenstra \& Ahsmann, 1980:19).

Daar is erken dat die owerheid beperkings op die wilsuitoefening kon plaas deur byvoorbeeld sekere ooreenkomste as ongeoorloof te bestempel (De Groot, $1664: 3.1 .19,3.1 .21$ en 3.1 .42$) .13$ Hierdie beperkings is gesien as in ooreenstemming met die natuurreg. By implikasie is dus erken dat sekere perke aan die privaatoutonomie van die mens deur die owerheid gestel kan word. 14 Teen die

12 'n Kontrak word deur die blote wilsooreenstemming van die partye tot stand gebring

13 Voorbeclde hicrvan is dic woekerverbod en sekere bepalings oor huurkontrakte en dienskontrakte (kyk De Groot, 1664:3.10.9, 3.10.10, 3.19.3, $319.6 \mathrm{cn} 3.19 .13$ ). Hicrdie beperkings het 'n uitwerking gehad op dic bestaan al dan nic van 'n kontrak Dit verskil van die geval wat tans van belang is, naamlik waar 'n geldige (maar onuitgevoerde) kontrak bestaan en op grond van wetteregtelike bepalings of andersins, as gevolg van dic sekwestrasic van een van dic partyc se boedel (ongeag dic wense van die teenparty) becindig kan word.

14 Perke kan gestel word op grond van die beginsel van geoorloofdheid Voorbeclde van bepalings wat aan die howe die kompetensie gegee het om met kontraktucle verhoudings in te meng, was die laesio enormis- en clausula rebus sic stanibus-lecrstukke (Fecnstra \& Ahsmann, 1980:21 e.v). Ingevolge ecrsgenoemde kon die hof 'n kontrak ongedaan maak indien die verkoper sy saak vir minder as die helfte van dic waarde daarvan verkoop het. Hicrdic bepalings is in dic Middelceue uitgebrei om ook die koper wat te veel betaal het te beskerm. Hierdic reel is vanaf die sestiende eeu geleidelik aan al hoc meer kritick onderwerp (Eisclen, 1988:60). Laasgenoemde lecrstuk het daarvoor voorsiening gemaak (cers deur middel van 'n stilswyend veronderstelde beding maar later langs die weg van die gocie-trou-beginsel [Feenstra \& Ahsmann, 1980:19]) dat dic kontrak nic afgedwing sou word nic indien onvoorsienc ver andering van omstandighede ingetree het (Feenstra \& Ahsmanı. 1980:23 c.v). Vanaf dic sewenticnde ecu het dic reel die meeste van sy betckenis in dic privaatreg verloor (Fecnstra \& Ahsmann, 1980:24) 
middel van die negentiende eeu was die beginsel van kontrakteervryheid goed ingeburger. 15 Dit ten spyt het veral die Engelse en Amerikaanse howe steeds op grond van billikheidsoorwegings met kontraktuele verhoudings ingemeng. Met ' $n$ nuwe geslag regters 16 het ' $\mathrm{n}$ nuwe benadering egter teen 1830 in hierdie lande begin posvat - ' $n$ benadering waarin die klem baie sterk op die vryheid en verantwoordelikheid van die individu geval het (Eiselen, 1988:71). Die sogenaamde onaantasbaarheid van 'n kontrak het in daardie tyd veral twee vryhede veronderstel, naamlik vergestaltingsvryheid en bemoeiingsvryheid (Printing \& Numerical Registering $v$ Sampson (1875) LR 19 Eq 462 465). Die howe se houding was dat dit in die openbare belang is dat partye se vergestaltingsvryheid so wyd moontlik moet strek, dat 'n hof daaraan gevolg moet gee en nie agterna daarnee behoort in te meng nie. Indien die kontrak vrywillig aangegaan is, behoort die hof dit net so af te dwing - ongeag die billikheid al dan nie van die inhoud (Eiselen, 1988:72).

In die Suid-Afrikaanse reg is die beginsel van die onaantasbaarheid van kontrakte na aanleiding van die Engelse reg aanvaar:

No doubt the condition is hard and onerous; but if people sign such conditions they must, in the absence of fraud, be held to them. Public policy so demands. 'If there is one thing which, more than any other public policy requires, it is that men of full age and competent understanding shall have the utmost liberty of contracting, and that their contracts, when entered into freely and voluntarily, shall be held sacred and shall be enforced by courts of justice' (Per Jessel, M.R. in Printing \& Registering Co v Sampson, LR $19 \mathrm{Eq}$ at $\mathrm{p} 465$ ).

In Marlin v Durban Turf Club and others (1942 AD 112 131) verklaar die hof:

The tendency of the law to hold persons to their contracts in such matters is also illustrated by a passage in Voet (4.8.9) stating that a person may appoint the advocate of his opponent as arbitrator, and if he does so, knowing that such advocate was acting for his opponent, there is no reason why he should not be prejudiced by his own free act to the extent of not being able afterwards to set up the nullity of the arbitration. Voet remarks that Van Leeuwen took a different view. I express no opinion on such a case, and merely quote the passage to show how far a weighty authority

15 Veral onder dic invlocd van dic lecrstellings van dic Franse fisiokraticse skool cn dic klassicke ckonomiese skool van dic laat agtiende en negenticude ecue onder leiding van Hume, Smith en Ricardo (Eisclen, 1988:66 71). Die invlocd van dic Franse en Engclse ckonome was nie beperk tot daardic lande waarin hicrdic ontwikkeling plassgevind het nic. Hulle invloed het na dic mecstc Europesc lande en lande binne hul invloedsfecr versprei.

16 Hierdic regters was gocd met dic bogenoemde ckonomiese rigting vertroud 
Kontraktuele geregtigheid, goeie trou en die optrede van 'n kurator ...

considered the Court might go in refusing to interfere with the contract of persons who have agreed on a certain tribunal.

In Roffey v Caterall, Edwards \& Goudré (1977 4 SA 494 (N) 505E-G) word die volgende houding ingeneem:

I am satisfied that South African law prefers the sanctity of contracts. That principle is firmly entrenched in our system, where it shows its head in so many places ... But its mercantile justification is not all there is to be said for the sanctity of contracts. The principle has a moral dimension too, which gives it a durability and a universality beyond the norms of the marketplace. This consists of its simple requirement that people should keep their promises.

\section{Kontrakteervryheid en die bevoegdheid van die kurator}

As die standpunt uiteindelik gehuldig word dat die kurator die regte uit 'n geldige kontrak mag beëindig, kom dit neer op 'n ondergrawing van diè beginsel, naamlik deurdat die kontrak nie gehandhaaf word soos die partye dit gesluit het nie Gevolglik is die kritieke vraag dan waarom toegelaat word dat die kurator met die kontraktuele verhouding van die insolvent en sy teenparty kan inmeng en ook geregtig is om spesifieke nakoming te weier, veral as in gedagte gehou word dat in Drewtons (Pty) Ltd v Carlie (1981 4 SA 305 (K) 317A-D) uitdruklik beslis word dat:

The concept of sanctity of contract is in my opinion one which requires jealous guarding by our Courts. ... Maintenance of the sanctity of contract and ensuring that parties abide by their agreements, seriously made ... is essential.

Skep die situasie by sekwestrasie dus 'n anomalie sodat 'n selfstandige beginsel geformuleer moet word om die "afwyking" te motiveer, of is dit tog op die regsetiese grondslag van goeie trou gegrond? Waarom is dit noodsaaklik om 'n norm te bepaal? In die ondersoek na die gedagte van kontrakteeruryheid blyk dit duidelik dat hierdie konsep steeds baie sterk trekke van die negentiende-eeuse liberalistiese beskouing van die beginsel vertoon. Dit beteken eerstens dat, aangesien die grootste gedeelte van die gemeenregtelike kontraktereg uit reëlende regsreëls bestaan, partye kragtens hulle vergestaltingsvryheid vryelik daarvan kan afwyk en dat hulle enige geoorloofde inhoud aan hulle ooreenkoms kan gee. Tweedens sal 'n hof nie ex post facto met die kontraktuele verhouding inmeng nie, maar dit afdwing soos die partye daarin ooreengekom het (Eiselen, 1988:75 
A.L. Stander

e.v.). Die gedagte van kontrakteervryheid in die omvattende $\sin 17$ oefen vandag nog steeds 'n groot invloed uit.

Ten spyte hiervan het die wetgewer reeds op talle terreine bepalings neergelê waardeur die sluitings-, vergestaltings- en bemoeiingsvrylheid van partye aangetas word $18 \mathrm{Al}$ die gevalle van wetgewende inmenging wat reeds bestaan, verteenwoordig meteen ook 'n inbreuk op die beginsel van kontrakteervryheid. Met betrekking tot die insolvensiereg kan kortliks na artikels 35, 36 en 37 van die Insolvensiewet (24 van 1936) verwys word, waar die wetgewer pertinent sekere regte aan een van die kontrakpartye gee wat hy/hulle nie sou gehad het as sekwestrasie nie plaasgevind het nie. Regverdiging vir hierdie inmenging deur die wetgewer moet gevind word. Die kontrakteervryheidbeginsel (in die sin dat die kontrak gehandhaaf word soos die partye dit gesluit het) kom ook in gedrang as uiteindelik bevind sou word dat die kurator geregtig is om 'n geldige kontrak te beëindig. Regverdiging vir so 'n algemene reel sal ook gevind moet word.

By die beoordeling van die posisie moet die volgende in gedagte gehou word: dit is eenvoudig fisies onmoontlik om ná insolvensie aan elke skuldeiser presies dit te gee waarvoor hy gekontrakteer het, want die insolvent se laste oorskry sy bates. 'n Skuldeiser behoort nie, ten spyte van die insolvensie van sy skuldenaar, steeds toegelaat te word om sy relatiewe posisie teenoor ander skuldeisers te verbeter niie. Regspolities sal so ' $n$ stand van sake indruis teen die algemene gevoel van wat reg en verkeerd is. Sodra die skuldenaar insolvent is, sal die betaling van die een skuldeiser noodwendig die ander benadeel, ondat daar onvoldoende bates is om aan alınal se eise te voldoen. Sekwestrasie, synde 'n proses van kollektiewe eisafdwinging, is 'n reaksie op hierdie soort potensiële nadeel. Onder meer beklemtoon die situasie by die sekwestrasie van 'n insolvente boedel slegs die standpunt dat nie een van die vorns van kontrakteervryleeid absoluut kan of behoort te geld nie. Daar bestaan 'n behoefte aan sekere perke vir hierdie vryhede om misbruik en ongeregtigheid te voorkom

Die vraag kan dus gestel word of dan aanvaar moet word dat die hantering van onuitgevoerde kontrakte in die insolvensiereg van die bestaande kontrakregtelike beginsels mag afwyk en nie daannee versoen hoef te word nie. Mag die objektiewe reg eenvoudig ingryp en mag dit eenvoudig aangepas word? Watter riglyne word gebrnik om behoorlike beregtiging van skuldeisers inter se te bewerkstellig? Kan dit na willekeur verander word? Die insolvensiereg behoort daarna te streef om 'n billiker stelsel daar te stel deur onregverdige regsreëls te

17 Kontraktecrvryheid dui op dic onwenslikhcid dat die owerheid enigsins die ander vorme van kontraktcervngheid aan bande le

18 Vir enkele voorbeclde ter illustrasic hicrvan, kỵk Eısclen (1988:76). 
Kontraktuele geregtigheid, goeie trou en die optrede van 'n kurator ...

identifiseer en nuwes in die plek daarvan te stel. Die korrekte benadering tot hierdie probleem is om as uitgangspunt te aanvaar dat die beginsels van 'n concursus creditorum vereis dat 'n sekere resultaat ten aansien van die verdeling van die opbrengs van die bates van die insolvente boedel tussen skuldeisers bewerkstellig moet word. Hierdie benadering impliseer dat alle skuldeisers se relatiewe posisies, soos wat dit op die oomblik van sekwestrasie bestaan, gehandhaaf word. Billikheid teenoor die skuldenaar (en na my mening in sekere omstandighede ook teenoor die ander kontrakparty) behoort ook bewerkstellig te word. Daar behoort egter sekere riglyne in ag geneem en sekere grense gestel te word wanneer die nuwe reêls geformuleer word. Die rede hiervoor is om billikheid teenoor alle betrokke partye te bewerkstellig. Waar daardie grense gestel moet word, is 'n vraag wat myns insiens aan die hand van geregtigheidsoorwegings en die oortuigings van die gemeenskap - met ander woorde met verwysing na die openbare belang soos dit in die vereiste van goeie trou tot uiting kom - bepaal moet word. As dit dus blyk dat die reels van die algemene reg nie hierdie resultaat bewerkstellig nie, moet daar, met verwysing na die vereiste van goeie trou, reels geformuleer word wat uitsluitlik in 'n concursus creditorum geld.

Voor 'n volledige motivering vir hierdie standpunt gegee word, is dit egter belangrik om eers te toets of die grondslag vir die inmenging van die kurator nie eerder op ' $n$ ánder beginsel gegrond is nie. Aan die orde is vervolgens die vraag of dit wel moontlik is om die situasie vanuit die beginsels van billikheid en algemene geregtigheid te regverdig. 19

\section{Grense waarbinne kontrakteervryheid uitgeoefen kan word}

Individuele kontrakteervryheid kan ook volgens Van der Walt (1989:82) nie sonder die gepaste beheer werklik tot sy reg kom nie. Die belangrike vraag is dan na die grense waarbinne toegelaat kan word dat die partye hulle kontrakteervryheid uitoefen, ook in die sin van bemoeiingsvryheid en in die sin van die afdwingbaarheid van 'n onuitgevoerde kontrak waar sekwestrasie van die boedel van een van die partye plaasgevind het.

Omdat die wetgewer slegs op 'n ad hoc-basis beskerming verleen $\mathbf{2 0}$ met die oogmerk om die verhouding tussen die partye op 'n billike wyse te reël, 21 en

19 Ek meen dat met reg ook gevra kan word of die clausula rebus sic stantibus-lecrstuk weer nuwe betckenis verkry het Is dit nic moontlik die uitsonderingskritcrium "onvoorsiene verandering van omstandighede" in 'n nuwe gedaante nie? Dic vraag word hicronder volledig bespreck

20 Soos byvoorbecid in dic geval van dic Wet op Kredietooreenkomste 75 van 1980 waar dic verbruiker en algemene ekonomıe van dic land beskerm word. Kyk ook die bepalings van dic Wet op Arbeidsverhoudinge 28 van $1956 \mathrm{cn}$ dic Wet op. Skadelike Sakepraktyke 71 van 1988. 
ondat die wetgewer origens huiwerig is om met die burgery se kontrakte in te meng, maak kontrakpartye gevolglik op die howe staat om die reg uit te bou en aan te pas en om billike oplossings vir nuwe omstandighede te vind.

\subsection{Billikheid as norm}

Kan 'n regter billikheid as norm aanwend wanneer hy gevra word om oor die geldigheid of afdwingbaarheid van die ooreenkoms te beslis?22 Eerstens word na die vraag gekyk of 'n spesifieke kontrak deur billikheid beperk of aangevul kan word. 23 Lotz (1979:6) wys daarop dat dit tog op bedekte wyse gebeur, byvoorbeeld wanneer die regter die kontrak interpreteer of bevind dat 'n stilswyende beding by die kontrak ingelees moet word. Hoewel die standpunt van die howe is dat daar geen algemene billikheidsjurisdiksie bestaan nie (North Vaal Mineral Co Ltd v Lovasz 19613 SA 604 (T); Zuurbekom Ltd v Union Corporation Ltd 19471 SA 514 (A); Technı-l'ak Sales (Pty) Ltd v Hall 19683 SA $231(\mathrm{~W})$ ), beteken hierdie stelling volgens Lotz (1979:7) slegs dat daar geen abstrakte billikheidsidee of -begrip as standaard vir die beoordeling van 'n bepaalde feitestel is nie. Op grond van billikheid ontstaan egter maatstawwe wat die billikheidsbegrip konkretiseer. Hierdie maatstawwe kan met ander woorde aangewend word om in 'n bepaalde geval oor die afdwingbaarheid al dan nie van 'n ooreenkoms te beslis. Hoe ver strek die billikheidsjurisdiksie? Om hierdie vraag sinvol te beantwoord, wys Lotz daarop dat dit belangrik is om die werking van billikheid by die sluiting en billikheid by die nakoming van die kontrak te onderskei (Lotz, 1979:11). Die reëls met betrekking tot wanvoorstelling, vreesaanjaging en onbehoorlike beinvloeding is billikheidsreëls wat by kontraksluiting ter sprake kom. Billikheidsreëls maak 'n kontrak vernietigbaar, want op grond van billikheid word geoordeel dat daar by die totstandkoming van die kontrak 'n wilsgebrek was. Billikheid het dus 'n beperkende werking by die totstandkoming van 'n kontrak (Lotz, 1979:16). Is dit ook die geval by die nakoming van die kontrak? Kan billikheid ook as maatstaf gebruik word om byvoorbeeld 'n ander persoon toe te laat om tot 'n kontrak toe te tree en die afdwingbaarheid van 'n onuitgevoerde kontrak in die geval van sekwestrasie te beperk? Lotz wys op die

$21 \quad$ Klaarblyklik kan dic bepalings van dic Inso/vensiewer 24 van 1936 met betrckking tot onuitgevocrde kontrakte ook hierby gereken word. Dic wetgewer het ook reeds in sekere gevalle aan dic hof die kompetensic verlecn om bepaalde kontrakte dirck aan billikheid te tocts, byvoorbceld a 3 van dic Wet op Strafbedinge 15 van 1962

22 Byvoorbceld waar dic kurator die kontrak wil becindig.

23 Van der Walt (1989:82) is van mening dat dic begınsels van kontraktecruryheid, konsensus en afdwingbaarheid ustgangspunte vertecnwoordig wat in openbare belang geld en in die gocietrou-vereiste van ons kontraktereg beliggaam word Dit is volgens hom die norm waaraan 'n kontrak getocts moet word. 
Kontraktuele geregfigheid, goeie trou en die optrede vall " kurator ...

bestaan van sekere gekristalliseerde reels wat op grond van billikheid die uitoefening van kontraktuele regte belet of beperk. Sodanige reells is byvoorbeeld die reel met betrekking tot die vermindering van huurgeld; die reel dat 'n borg van sy verpligting bevry word indien die skuldeiser deur sy onredelike optrede of deur toeskietlikheid teenoor die skuldenaar die borg se verpligting verswaar; die reēls in verband met onmoontlikwording van prestasie en met betrekking tot die exceptio non adimpleti contractus. Ook na analogie van hierdie genoemde voorbeelde kan die grondslag van die toepaslike bepalings van die Insolvensiewet moontlik verklaar word. Die doel van die Wet is juis om 'n billike en gelyke behandeling van die skuldeisers van 'n insolvente boedel en 'n billike en regverdige verdeling van die bates van daardie boedel te bewerkstellig (Smith, 1988:4). Slegs 'n buitestaander in die persoon van die kurator, toegerus met die nodige statutêre kompetensies en bevoegdhede, sal kan toesien dat dit wel geskied.

Met betrekking tot die gevalle waarvoor die wetgewer nié voorsiening gemaak het nie, moet derhalwe 'n verdere ondersoek na die grondslag vir die inmenging van die kurator en die weiering van spesifieke nakoming van die kontrak gedoen word. Die logiese vraag is dan of daar 'n algemene billikheidsmaatstaf bestaan? Volgens die regspraak is dit nie die geval nie. Dit is egter Lotz se uitdruklike standpunt dat dit wel die geval behoort te wees waar die onbillike werking van die kontrak ontstaan het as gevolg van die gepoogde afdwing daarvan in omstandighede wat tydens die sluiting van die kontrak, na die wete van die skuldeiser, nie deur die partye of die skuldenaar oorweeg is nie (Lotz, 1979:18). Ook word die behoefte aan so 'n algemene billikheidsmaatstaf by 'n verandering van die feitelike omstandighede na kontraksluiting deur Lotz uitgespel. Daarvoor sal volgens hom gevra word hoe voorsienbaar die omstandighede tydens kontraksluiting was en in welke mate die skuldenaar se posisie verswaar is. Uiteindelik moet die regter dan elke geval aan die vereiste van goeie trou toets (Lotz, 1979:18).

Dat billikheid wel 'n rol by onuitgevoerde kontrakte speel, is waar. ${ }^{24}$ In die lig egter van die oorheersende standpunt dat enige kontrakparty in elke geval die risiko van die insolvensie van sy teenparty loop, dat dié risiko dus binne die alledaagse bedryf van besigheid val, sal weliswaar nie aan die bogemelde onvoorsienbaarheidskriterium voldoen kan word nie. Verder, om op grond van billikheid ' $n$ beslissing te maak, word in elk geval aan die hand gedoen dat die regter die betrokke geval aan die vereistes van goeie trou moet toets. Daarom is

24 Dit is net billik dat aan dic kurator dic keuse gegee word om te besluit of dit tot voordecl van dic boedel sal wees om 'n sckere kontrak uit te vocr en daardeur 'n wins vir die bocdel te bewerkstellig. Sodocnde word dic concursus creditorum bevoordecl. Dit is ook billik dat al dic skuldeisers gelyke behandeling ontvang. 
ek van mening dat die beginsel van goeie trou eerder as norm erken moet word as om billikheid tot die norm te verhef. Myns insiens is die billikheidsnorm ook nog te vaag en nie voldoende deur die howe gevorm om as algemene maatstaf 'n beperkende werking by eise vir die nakoming van kontrakte te hê nie.

\subsection{Kontraktuele geregtigheid en goeie trou as norm}

As dit nie aanvaar word dat billikheid die dominante maatstaf vir die toetrede van die kurator tot die onuitgevoerde kontrak van die insolvent is en dat dit ook as maatstaf met 'n beperkende werking ten opsigte van die nakoming van 'n onuitgevoerde kontrak geld nie, is die volgende vraag of die beginsel van algemene geregtigheid moontlik as motivering kan dien vir die inmenging deur die kurator en die weiering van spesifieke nakoming. Volgens Van der Walt is die kemvraag in verband met algemene geregtigheid of die bestaande toedeling van juridiese, sosiale en ekonomiese middele en geleenthede, vir sover dit per kontrak geskied, in die betrokke gemeenskap aan die een of ander gelykheidsideaal voldoen. Algemene geregtigheid het te make met die nodigheid en wenslikheid vir die verandering van die gemeenskap waarbinne die kontrak aangewend word (Van der Walt, 1989:81 e.v). Kortliks sal met die opmerking volstaan word dat algemene geregtigheid nie as maatstaf vir die oplossing van die onderhawige vraag aangebied kan word nie. Dit is my mening dat die kontraktereg nie in hierdie opsig met so 'n vae gegewe kan werk nie. Met betrekking tot die beginsel van kontraktuele geregtigheid, wat enger as algemene geregtigheid is, is Van der Walt se standpunt dat die ondeurdagte afdwinging van kontrakte, ongeag die gevolge daarvan, in stryd is met die geoorloofdheidsgedagte soos uitgedruk in die goeie-trou-grondslag van ons kontraktereg 25

Volgens die beginsel van kontraktuele geregtigheid is die maatstaf die volgende: Wat vereis die openbare belang van kontrakte en kontrakpartye? Dit word beliggaam in die goeie-trou-vereiste val die Suid-Afrikaanse kontraktereg. Openbare belang het in verband met die afdwing van kontrakte twee teenstrydige oogmerke, naamlik sowel verreikende kontrakteervryheid as die beperking daarvan in ooreenstemming met die breë geoorloofdheidsgedagte aan die hand van die goeie trou (Van der Walt, 1989:86) 26 Die openbare belang in hierdie sin bepaal myns insiens ook die grense waarbinne toegelaat word dat met die

25 Hy sock daarom dic oplossing vir dic problccm - soos byvoorbecld in dic geval van onbillike standaardbedinge - in die gocic-trou-vereistc, in teenstelling daamec on billikheid tot die norm tc verhef. Ook Swart (1990:74) mecn dat billikhicid nic dic enigstc of dominante oorweging vir dic eksklusicwe insolvensicproses is nic.

26 Van Zyl (1988:272 290) verklaar dat gocic trou as beginsel deur dic reg in ag gencem moct word om orde cn geregtigheid te bewerkstellig (kyk ook Corbett, 1987:52)

Koers 61(2) 1996:213-235 
Kontraktuele geregtigheid, goeie trow en die optrede van 'n kurator ...

beginsel van bemoeiingsvryheid ingemeng mag word. Kan die oorname van 'n onuitgevoerde kontrak deur die kurator van 'n insolvente boedel, ten spyte van die inbreuk wat noodwendig daardeur op die bemoeiingsvryheid van die teenparty gemaak word, na analogie hiervan gesien word asof dit op die herstel van kontraktuele geregtigheid gemik is? 27 Die vraag is dus of die grondslag vir die ondergrawing van die beginsel van kontrakteervryheid, in die sin dat die kurator die regte uit 'n kontrak mag beëindig, nie ook die vereiste van openbare belang - soos in die goeie-trou-vereiste beliggaam - is nie. Hierdie vraag noodsaak 'n ondersoek na die kristallisering van die openbare belang by die sekwestrasie van ' $n$ insolvente boedel. As insolvensie nie ter sprake is nie, vereis die openbare belang myns insiens goeie trou inter partes. Ná sekwestrasie tree die openbare belang in die vorm van die concursus creditorum sterker na vore. As die kontrak ten spyte van sekwestrasie ten volle uitgevoer word, kan dit in werklikheid gebeur dat die betrokke kontrakparty (solvente party by kontrak A) se kontrakteervryheid $\mathbf{2 8}$ onder daardie omstandighede ten koste van ander kontrakterende partye (solvente partye by kontrakte B, C en D) se kontrakteervryheid $^{29}$ gehandhaaf word. Die dilemma is dat een skuldeiser se kontrakteervryheid, weens die oorbeklemtoning daarvan, 'n ander skuldeiser se kontrakteervryheid kan beperk of uitskakel. Hierdie beperking van kontrakteervryheid kan as strydig met die ekonomiese doel van die sekwestrasieproses, openbare belang en goeie trou aangemerk word. Dit bly immers 'n probleem om te besluit aan watter een van verskeie kontrakterende partye se kontrak uitvoering gegee moet word. Dit is net logies dat nie aan al die kontrakte voldoen kan word nie - die teenparty is tog insolvent. Dit bly dus problematies om te besluit watter een van die verskeie kontrakterende partye moet besluit watter kontrak uitgevoer gaan word 30

27 Dic voortsetting van dic recls wat skuldeisersverhoudinge onder solvente omstandighede regulecr, het irrasioncle optrede deur dic skuldeisers tot gevolg (tot nadecl van dic groep in geheel) Die rol van die insolvensicreg is juis om 'n oplossing vir hicrdic problecm te vind Dic historicse rol van dic insolvensicreg was nog altyd om 'n meganisme te skep wat rasionele optrede tot gevolg sal he - rasioncle optrede wat dic skuldeisers as 'n grocp sal bevoordocl. Dic ondcurdagte afdwinging van kontrakte ongeag dic gevolge daarvan, kan dic vertrouse van dic gemeenskap in die kontraktereg en dic regstelsel in dic gehecl toenemend in die wiele ry

28 Kontraktecrvryheid word hier gebruik in die sin dat die solvente kontrakparty volle uitvocring van sy kontrak verg sonder enige inmenging van dic kurator of concursus creditorum

29 In die sin dat daar dan uiters min of geen bates in die insolvente boedel is om an hulle kontrakte uitvoering te gee nic

30 Van der Walt (1989:87) wys op dic hedendaagse mening dat die openbare belang sonder meer gedien word deur dic afdwing van alle kontraktc wat aangegaan is. Enige beweging in dic rigting om wedersydse kontrakteervṇticid en dic gocic-trou-vereiste as grondslag van ons geykte kontrakteregtcoric op alle fasctte van alle kontrakte to te pas, word openlik of op 'n bedekte 
A.L. Stander

Die concursus creditorum is myns insiens die vergestalting van die openbare belang by insolvensie. Die rede daarvoor is dat kontraktuele geregtigheid teenoor die groep en relatiewe onreg teenoor die een, te verkies is bo kontraktuele geregtigheid teenoor een en relatiewe onreg teenoor die groep skuldeisers. Dit bring ' $n$ mens uit by die beginsel van goeie trou en die vraag wat dit by die sekwestrasie vall die boedel van een van die partye tot ' $n$ onuitgevoerde kontrak vereis.

Reeds in die Romeinse reg het die howe 'n baie wye billikheidskompetensie gehad ingevolge waarvan die regte en verpligtinge van die partye deur die hof aangevul of beperk kon word (Tuckers Land \& Development Corporation (Pty) Lid v Hovis 19801 SA 645 (A) 651E-F). Die goeie-trou-vereiste hou verband met die gemeenskapsopvatting oor redelikheid, geregtigheid en billikheid (op 652C). Aangesien die gemeenskapsoortuiging nie 'n vaste onveranderlike is nie, maar met verloop van tyd mag verander, maak dit van die goeie-trou-vereiste 'n baie plooibare regsinstrument (Eiselen, 1988:168). Die vereiste van goeie trou word gekoppel aan die redelike verwagting van die teenparty (Tuckers Land \& Development Corporation (Pty) Lid v Hovis 1980 l SA 645 (A) 653B-C). Optrede wat in stryd is met redelike verwagtings wat by die teenparty opgewek is of wat dit ondermyn, sal dus op gedrag in stryd met die goeie-trou-vereiste neerkom.

Indien hierdie benadering ten opsigte van onuitgevoerde kontrakte in die insolvensiereg toegepas sou word, is sekere aanpassings nodig. Dit is so omdat vтаe oor goeie trou beantwoord moet word in die verband waarbinne dit gebruik word:

Concepts such as justice, equity, good faith and boni mores contain strongly subjective elements when they pertain to a particular person or a specified group of people. What is meant by these concepts depends on, and is inextricably linked to the personal circumstances of the particular person or group of persons. It has equally strong links, however, with the surrounding circumstances and with general considerations relating to these concepts to which the person or group of persons belongs (Van Zyl, 1988:290).

Goeie trou is na my mening die kristallisering van die openbare belang laasgenoemde soos wat dit by sekwestrasie manifesteer; derhalwe word weer eens beklemtoon dat, met betrekking tot die insolvensiereg, 'n skuldeiser nie toegelaat behoort te word om sy relatiewe posisie teenoor ander skuldeisers te

wyse teengestaan. Veral op dic gebied van dic insolvensicreg is hicrdie teenstand nié geregverdig nic Alle onuitgevoerde kontrakte kan nic sonder meer afgedwing word nie, omdat daar nic voldoende bates in die insolvente boedel is nic. Dit is tog dic rede waarom in sekwestrasicbevel tocgestaan is. 
Kontraktuele geregtigheid, goeie tron en die optrede val '" kuralor ...

verbeter nie. Sekwestrasie is 'n proses van kollektiewe eisafdwinging. Hoewel die toets met verwysing na die goeie-trou-vereiste ook in hierdie verband objektief is, moet daar myns insiens ook gekyk word na wat die verwagtinge van die concursus creditorum is en nie net na die subjektiewe verwagting van die betrokke teenparty nie. ${ }^{31}$ Daar moet gekyk word of die uitvoering van die kontrak, objektief gesien, alle skuldeisers (met inagneming van die voorkeurorde) in gelyke mate sal bevoordeel. Daar moet ook gekyk word of die uitvoering van die kontrak, objektief gesien, die concursus creditorum onredelik sal benadeel. As die netto resultaat van die betrokke kontrak ' $n$ bate is, moet die kurator dit in stand hou ten einde die grootste dividend vir die groep skuldeisers te kan verseker. As die netto resultaat ' $n$ las vir die boedel is, moet dit uit hoofde van die goeie-trou-vereiste geregverdig wees om aan die kurator die keuse te verleen om daardie kontrak te verwerp.

Die voorkeur vir kontraktuele geregtigheid teenoor die groep kom, wat die insolvensiereg betref, weer tot uitdrukking as kristallisering van die goeie-trouvereiste in die konsep "voordeel vir die skuldeisers" en die hele wyse waarop die kurator sy ampspligte moet uitvoer. Daar moet dus in gedagte gehou word dat die sekwestrasieproses en die administrasie van die boedel deur die kurator as doel het om vir die skuldeisers as 'n groep die maksimum dividend te verkry. As die keuse van die kurator om nie met die kontrak voort te gaan nie tot gevolg het dat die boedelbates optimaal aangewend word, blyk dit dat die kompetensie van die kurator nié in stryd met hierdie algemene beginsel sal wees nie. Deur só op te tree sal hy dus nie sy plig versuim om die boedelbates te maksimaliseer nie. ${ }^{32}$ Maksimalisering van boedelbates is egter nie die enigste rede waarom die kurator geregtig is om die insolvent se verpligtinge te verwerp nie. Die rede vir die keuse om 'n kontrak te verwerp - weer eens uit hoofde van die goeie-trou-vereiste - lê ook in die kurator se verpligting om te sorg dat die relatiewe posisies van die betrokke skuldeisers, soos dit op die oomblik van sekwestrasie bevries is, in die sekwestrasieproses gehandhaaf word. ${ }^{33}$ In hierdie mate kontroleer die goeie trou myns insiens die inhoudelike van die optrede van die kurator; daarom word die kurator se besluit om die een kontrak uit te voer, maar om nie uit hoofde van die ander te presteer nie, ook aan die hand van die goeie trou getoets. As 'n mens na

31 In hicrdic sin is dic tocts met verwysing na dic gocic-trou-verciste dus nic objckticf nic. Dic voordcel van dic concursus creditorum wceg swaarder as dic nadecl van dic tecnparty.

32 As dic kurator dic kontrak verwerp, beteken dit gecusins dat dic kurator geregtig is om 'n geldige cis teen dic boedel te ignorecr nic. Daar kan nic van die ander kontrakparty ontslac geraak word nic

33 Verwerping van dic kontrak het dus ook in invlocd op dic wyse waarop dic beskikbare bates vcrdeel gaan word 
A.L. Stander

die positiewe reg kyk, is dit duidelik 'n behorensvraag wat aan die hand van openbare beleid kristalliseer.

Ek is oortuig dat immenging of oomame deur die kurator geregverdig kan word op grond van kontraktuele geregtigheid, openbare belang en goeie trou. Terselfdertyd kan dit as toetssteen dien om te verseker dat sodanige ingrype op 'n teoreties houdbare en prakties uitvoerbare wyse geskied.

\section{Die wederkerigheidsbeginsel van die kontraktereg34}

By kontrakte ingevolge waarvan albei kontrakpartye uitstaande verpligtinge het, besit die partye 'n weerhoudingsbevoegdheid oor hul eie ongelewerde prestasies. By sommige kontrakte (wederkerige kontrakte) waaruit wedersydse verpligtinge voortvloei, word wesenlik 'n uitruiling van prestasie beoog. Onder andere is die gevolg dat die een party nie verplig is om sy prestasie te verrig nie alvorens die ander party op sy beurt sy teenprestasie verrig. Hierin lê dan die bevoegdheid opgesluit van die een party om sy eie prestasie te weerhou totdat die ander presteer 35

Die wederkerigheidsbeginsel, met sy meeganger die exceptio non adimpleti contractus, het in die klassieke Romeinse reg ontspring. Dit blyk dat dit deur die Glossatore geformuleer is, in Europa geresipieer en in die onderskeie nasionale regstelsels opgeneem is. Sodoende het dit vanaf Holland ook by ons in SuidAfrika uitgekom (kyk BK Tooling (I:dms) Bpk v Scope Precision Engineering (Edms) Bpk 19791 SA 391 (A) 417; Jaeger, 1978(6):663). In die Romeinse reg, as 'n aksie deur 'n party gebring is, kon die regter beslis dat die eiser in stryd met goeie trou optree deur prestasie te eis sonder om sy deel van die kontrak na te kom. 'n Party wat sy belofte verbreek het, is sodoende verhoed om die ander se prestasie af te dwing (Jaeger, 1978(6):663).

Wesenlik is die weerhoudingsreg 'n middel om teenprestasie mee af te dwing. Eie prestasie kan dus weerhou word totdat die teenprestasie volledig geskied ( $B K$ Tooling (I:dms) Bpk v Scope Precision lingineering (Edms) Bpk 19791 SA 391

34 Kyk in hicrdic verband dic uitecnsctting in BK \%ooling (I:dms) Bpk $v$ Scope Precision lengineering (Edms) Bpk 1979 I SA 391 (A)

35 Gericflikhcidshalwe sal voortaan van dic "wederkerighcidsbeginsel" gepraat word. Dic bevocgdheid on 'n prestasie as uitvlociscl darvan terug te hou, sal dic "wecrhoudingsreg" genoem word. Na die verweer wat laasgenocmde bied as die party deur die teenparty angesprock word, sal as dic exceptio (dit wil sĉ non adimpleti contrachus) verwys word. 
Kontraktuele geregtigheid, goeie tron en die optrede vam " kurator

(A) 420). ${ }^{36}$ Hierdie verband wat deur wederkerigheid geskep word, word nie geraak deur die sekwestrasie van die boedel van 'n party tot so 'n kontrak nie (Cohen NO and others $v$ Verwoerdhurg Town ('ounc:l 1983 I SA 334 (A) 352). 'n Beginsel wat nog altyd deur die howe erken is, is dat 'n kurator wat uitvoering wil gee aan 'n kontrak wat voor sekwestrasie gesluit is, nie prestasie kan eis nie tensy hy bereid is om of ten volle te presteer of volle prestasie van al die insolvent se verpligtinge aan te bied, insluitend onvervulde prestasies van die verlede. As hy weier om te presteer kan hy as gevolg van die teenparty se weerhoudingsreg self ook nie prestasie eis nie. Daar kan dus nooit 'n benadering gevolg word ingevolge waarvan die teenparty ná sekwestrasie moet presteer en dan 'n konkurrente eis vir die teenprestasie het nie. Hierdie beginsel behoort dus nie deur sekwestrasie in die wiele gery te word nie (kyk ook Reinecke \& Cronje, 1979:389 394; Swart, 1990:473). Dit laat die idee van pacta servanda sunt ten minste ten dele geld. Hoewel instandhouding tot gevolg het dat die teenparty se eis ten volle bevredig word, is hy as gevolg van sy weerhoudingsreg op die oomblik van sekwestrasie in 'n beter posisie as konkurrente skuldeisers. Net soos ' $n$ skuldeiser wat 'n saak van sy skuldenaar in pand hou, is die teenparty in besit van 'n potensiële bate ${ }^{37}$ van die insolvente boedel, naamlik sy eie teenprestasie. Hierdie bate kan hy aanwend om sy eis teen die insolvent te bevredig.

Die analogie tussen die posisies van 'n pandhouer en 'n kontrakparty wat oor 'n weerhoudingsreg beskik, is reeds in die Romeinse reg geïdentifiseer. As gevolg van sy weerhoudingsreg is die teenparty in dieselfde posisie as ' $n$ versekerde skuldeiser. Hy moet derhalwe soos 'n versekerde skuldeiser behandel word. Net soos 'n pandhouer se eis tot die waarde van die pandsaak verseker is, is die teenparty se eis tot die waarde van sy eie uitstaande teenprestasie verseker (Swart, 1990:443 e.v.). ${ }^{38}$

'n Argument is vervolgens dat die solvente kontrakparty, met die repudiëringskonstruksie as uitgangspunt, die idee van pacta sunt servanda minstens ten dele laat geld. 39 So byvoorbeeld, as die kurator die verpligtinge uit hoofde van 'n

Dit kan aanvaar word dat as enige onvolledigheid van dis teenprestasic onder dic de minimis beginsel tuisgcbring kan word, dic exceptio nic sal gcld nic. Dit is dus moontlik dat dic konsckwente toepassing van die beginsel van wederkerigheıd tot onbillikhede kan lci

37 Die vorderingsreg (op prestasic) is dic bate, en nic dic teenprestasic self nic, minstens tot op dic stadium dat die teenprestasic gelewer is

38 Hy verklaar dat al kan dic tcenparty niks van dic bocdel cis nic, dic wecrhouding van dic prestasic tot gevolg het dat sy eis by wyse van skuldvergelyking tot dic bedrag van hicrdic verskuldigde prestasic vereffen is

39 As dic standpunt ingeneem word dat dic kurator by magte is om dic kontrak te becindig. sal dit natuurlik nie moontlık wees nie. 
onuitgevoerde kontrak "repudieer", kan die solvente kontrakparty dit ignoreer. Die kontraktuele regte en verpligtinge bly voortbestaan, met dien verstande dat die wederkerigheidsbeginsel steeds in ag geneem sal moet word. Aanhangers van die repudiëringskonstruksie verklaar nou dat hierdie reel in 'n belangrike opsig gekwalifiseer moet word. Die onskuldige kan immers nie verwag om spesifieke nakoming te verkry nie. As hy verkies om die kontrak uit te voer, sou hy tevrede moet wees met 'n konkurrente dividend in plaas van die volle teenprestasie (vgl. Reinecke \& Cronje, 1979:395). As die teenparty egter op die "repudiëring" reageer en terugtree, kan hy 'n konkurrente dividend op die insolvent se prestasie bekom. Oënskynlik handhaaf die repudiëringsknnstruksie die wederkerigheidsbeginsel dus ook in die geval van sekwestrasie. 40

\section{Gevolgtrekking}

De Groot het die klem op die bindende krag van 'n erustige belofte geplaas en daarop gewys dat dit 'n oortuiging uit die natuurreg is dat ooreenkomste wat vrywillig aangegaan is, nagekom moet word. Hoewel die mens 'n vrye, outonome en rasionele wese is wat heerskappy oor sy goed en oor homself voer en daarom in staat is om daannee volgens sy eie goeddunke te handel, terwyl die reg daaraan gevolg behoort te gee, is dit nie die geval met die sekwestrasie van sy boedel nie. Op hierdie stadium voer die insolvent nie meer heerskappy oor sy eie goed nie. Ter wille van ekonomiese oorwegings, geregtigheid en goeie trou word hy teenoor die concursus creditorum nie toegelaat om daarmee te handel volgens goeddunke nie

Billikheid alleen is nie die basis waarop die afdwing van die kontrak geweier kan word nie; dit is wel 'n belangrike faktor. Myns insiens is die openbare belang soos dit in die vereiste van goeie trou tot uiting kom die regverdiging vir die reẹl dat afdwinging geweier kan word. Nog 'n wyse waarop die vereiste van goeie trou in die geval van sekwestrasie kristalliseer (en dus as verdere motivering van my standpunt kan dien), is die volgende: in die Romeins-Hollandse reg was dit aanvanklik moontlik dat 'n kontrak op grond van onvoorsiene verandering van omstandighede, uit hoofde van die clausula rebus sic stantibus-leerstuk, nie afgedwing is nie. Aanwysings met betrekking tot sodanige omstandighede was byvoorbeeld wanneer die afdwing van die kontrak tot ongeoorloofdheid

40 Word egter dic standpunt verkics dat die kurator dic kcuse moet hê om die kontrak te verwerp, is daar myns insıens voldoende gesag dat dic kurator ook dán nic kan cis dat dic tecnparty sy verskuldigde prestasic lewer nic. As hy onder hicrdic omstandighede verplig kon word om sy prestasic aan dic bocdel te lewer en daanla as konkurrente skuldeiser moet eis vir wat dic insolvent aan hom verskuldig is, sou dit tot gevolg hê dat dic teenparty se relaticwe posisic soos wat dit op dic oomblik van sckwestrasic bestaan, in 'n groot mate verswak word. Hy kan nie dic voordecl van sy weerhoudingsreg ontncem word nic 
Kontraktuele geregtigheid, goeie tron en die optrede van 'n kurator ...

aanleiding sou gee, wanneer dit meer skade vir die party wat belowe het as nut vir die teenparty sou inhou; wanneer prestasie te swaar en ondraaglik sou wees (Feenstra \& Ahsmann, 1980:23 e.v.). Daar is ook gewys op die feit dat die leerstuk reeds in die sewentiende eeu die meeste van sy betekenis verloor het. Dit was ook die opvatting in die negentiende eeu:

\begin{abstract}
... een interpretasie die men in samehang moet zien met de toen verkondigde opvatting dat de rechter ook met een beroep op het goede trouw-beginsel van artikel 1374 lid 3 contractuele verpligtingen opzij kan zetten. Tegen de achtergrond van derglike opvattingen was voor de clausula als algemeen erkend geen plaats. ... De Hoge Raad bleef, maar meestal word aangenomen, vasthouden aan het standpunt dat het goede trouw-beginsel geen contractuele verpligtingen opzij kan zetten. Door een aantal moderne rechtsgeleerde schrijvers is echter protest tegen dat standpunt aangetekend en in het Nieuw Burgerlijk Wetboek is dan ook een bepaling opgenomen die aan de rechter wél de bevoegdheid geeft om een overeenkoms te wijzigen of te ontbinden o.g.v. onvoorziene omstandigheden welke van dien aard zijn dat de wederpartij naar maatstaven van redelijkheid en billijkheid ongewijzigde instandhouding van de overeenkoms nie mag verwachten. Hoewel hier de oplossing niet in de constructie van een stilzwijgende voorwaarde word gezocht, word dit artikel toch wel als een 'clausularegeling' aangeduid (Feenstra \& Ahsmann, 1980:24-25). ${ }^{41}$
\end{abstract}

As inmenging deur die kurator nodig is omdat al die kontrakte van die insolvent nie afgedwing kan word nie, maar dit nie aanvaarbaar of werkbaar is om die grondslag daarvan op billikheid of geregtigheid (uitgedruk in terme van goeie trou) te vestig nie, is die vraag of verandering van omstandighede in die sin van die clausula-beginsel nie in hierdie sin ook in die Suid-Afrikaanse reg herlewe het nie. Kwalifiserende omstandighede behoort dan daardie te wees wat na die sluiting van die kontrak ontstaan het, soos sekwestrasie van die boedel van een van die kontrakpartye. Dit is duidelik dat die boedel se posisie dan "ondraaglik" verswaar het; daarom is dit gesekwestreer. In dié besondere omstandighede word ook aan die goeie-trou-vereiste voldoen, want as een solvente kontrakparty toegelaat sou word om prestasie teen die boedel af te dwing, sou dit nie redelik en billik teenoor die concursus creditorum wees nie. Om te kan slaag sal daar egter ook gevra moet word hoe voorsienbaar hierdie verandering tydens kontraksluiting was. Was dit nie redelikerwys voorsienbaar nie, kan dié uitsonderingsreèl ${ }^{\mathbf{2}}$ wel van toepassing wees. Hierdie laaste vereiste kan probleme skep. Indien 'n mens die standpunt huldig dat enige kontrakparty in elke geval die risiko van die insolvensie van sy teemparty loop, dat dié risiko dus

41 Fecnstra wys daarop dat dic Duitsc regspraak wel dic clanssu/a-gedagte aanvaar het

42 Naamlik dic clausula rebus sic stantibus. 
binne die alledaagse bedryf van ' $n$ besigheid val, is 'n huiwering om die terugkeer van dié leerstuk onvoorwaardelik te erken geregverdig.

Dit is ook moontlik om te argumenteer dat dit in die geval van sekwestrasie van een van die partye se boedels oor 'n selfstandige beginsel gaan. Dit is eenvoudig 'n feit dat dit onmoontlik is om volle gevolg aan die aansprake van al die skuldeisers te gee. ${ }^{43}$ Dit is juis die voortsetting van individuele remedies onder insolvente omstandighede wat die probleem van ongelyke en onregverdige behandeling van die skuldeisers as ' $n$ geheel veroorsaak. Dit volg dus dat daar onder insolvente omstandighede 'n dringende behoefte aan 'n kollektiewe eksekusieproses bestaan. Hierdie eksekusieproses moet onder beheer en toesig van 'n buitestaander in die persoon van 'n kurator of voorlopige kurator geskied; daarom is dit noodsaaklik dat hy die regte en verpligtinge uit hoofde van die onuitgevoerde kontrakte van die insolvent verkry; daarom ook die reel dat die kurator nie gedwing kan word om ingevolge 'n nog onuitgevoerde kontrak te presteer nie. Die feit dat dit ook 'n billike reeling is en aan die geregtigheidsideaal voldoen, versterk net die standpunt dat dit 'n gesonde en werkbare beginsel daarstel.

Die werkswyse in hierdie geval is dus om te erken dat die algemeen geldende reel met betrekking tot die uitvoering of nakoming van kontrakte in die geval van sekwestrasie tot 'n anomalie lei. Gevolglik is dit nodig om die hantering van die probleem te verklaar asof dit op 'n selfstandige beginsel gegrond sou wees. Deur egter te erken dat 'n weiering deur die kurator om met die kontrak voort te gaan, op goeie trou gegrondves is en deur die openbare belang geregverdig word, word die slaggate van bogenoemde werkswyse vermy. Reels soos onder andere dat die boedel van die insolvent onder die beheer en toesig van ' $n$ buitestaander in die persoon van 'n kurator moet geskied; dat die kurator die regte en verpligtinge uit hoofde van die onuitgevoerde kontrak verkry; dat hy 'n keuse het om nie 'n uitstaande verpligting ingevolge daardie kontrak uit te voer of na te kom nie; dat die teenparty nie spesifieke nakoming kan eis nie, is nou nie meer "anomaliee"" nie: dit is reels wat algemeen by die sekwestrasie van die boedel van een van die kontrakpartye geld. Ter ondersteuning van die argument kan daarop gewys word dat dit die openbare belang is wat vereis dat die kurator ' $n$ amp uitoefen.

Die bestaan van 'n bestuursverband tydens die sekwestrasieproses is die kristallisering van die openbare belang wat op die manier sterk na vore tree. Die reëls van die insolvensiereg verteenwoordig derhalwe ook uitgangspunte wat in

43 Dit is daarom irrelevant dat die solvent met dic repudicringskonstruksic as uitgangspunt dic idec van pacta servanda sunt minstens ten dele kan laat geld. 
Kontraktuele geregtigheid, goeie trou en die optrede van 'n kurator...

die openbare belang geld en in die goeie-trou-vereiste van ons kontraktereg beliggaam word.

Wat ook nie uit die oog verloor mag word nie is dat dit tog ook noodsaaklik is om, op grond van openbare belang en goeie trou, 'n gesonde balans tussen die beginsel van afdwingbaarheid van kontrakte en die beginsel van gelyke behandeling van die concursus creditorum te soek. In die insolvensiereg is dit baie duidelik dat die posisie van die concursus creditorum uiters belangrik is en die belange van ander domineer. Met betrekking tot onuitgevoerde kontrakte is die vraag egter wat dan word van die "gesonde" balans soos dit vereis word deur die openbare belang en die vereiste van goeie trou. Daar bestaan na my mening gevalle waar die teenparty tog die kontrak kan afdwing omdat die uitvoering van die kontrak 'n stadium bereik het dat die posisie van die concursus creditorum geensins deur afdwinging geraak sal word nie. Dan moet uitdruklik erken word dat ook die teenparty, uit hoofde van die beginsel van goeie trou, op die afhandeling van die onuitgevoerde kontrak kan aandring en op die beginsels van bemoeiingsvryheid en afdwingbaarheid kan steun. Welke gevalle hier ter sprake is, is myns insiens waar daar geen uitstaande verpligting aan die kant van die insolvente boedel meer is nie; dit is met ander woorde die gevalle waar die insolvent sy kontraktuele verpligtinge volledig nagekom het. Dan het die kurator geen ander keuse as om die insolvent se eis teen sy teenparty in te vorder nie.

\section{Bibliografie}

CORBETT, M.M. 1987 Aspects of the role of policy in the evolution of our common law South African Law Journal, 104(1):52-69.

DE GROOT, H. 1664 Inleydinge tot de Hollandsche rechts-geleertheyt Delft : Aernold Bon.

DE WET, J.C. \& VAN WYK, A H. 1992. Die Suid-Afrikaanse Kontraktereg en Handelsreg. Vol 1. 5de druk. Durban : Butterworths

EISELEN, G.T.S. 1988. Die beheer oor standaardbedinge: 'n regsvergelykende ondersoek Potchefstroom : PU vir CHO (LL.D.-proefskrif)

FEENSTRA, R \& AHSMANN, M 1980 Contract: aspecten van de begrippen contract en contractsvrijheid in historish perspektief. 2de uitg. Deventer : Kluwer

JAEGER, H E., e.a. 1978. Williston's treatise on the law of contracts. Vol. 6. 3de druk. New York : Baker Voorhis.

KERR, A J. 1989. The principles of the law of contract. 4de druk. Durban : Butterworths

LOTZ, J.G. 1979. Die billikheid in die Suid-Afrikaanse kontraktereg. Intreerede. Pretoria : Universiteit van Suid-Afrika.

REINECKE, M.F.B. \& CRONJE, D S P 1979. Eiendom op die huurkoopsaak en kansellasie van onuitgevoerde kontrakte by insolvensie van die huurkoopverkoper. Tydskrif vir Hedendaagse Romeins-Hollandse Reg, 42(1):389-402.

SMITH, C.H. 1988. The law of insolvency 3de druk Durban: Butterworths

SWART, B H. 1990 Die rol van 'n concursus creditorum in die Suid-Afrikaanse insolvensiereg Pretoria : Universiteit van Pretoria. (LL D -proefskrif.)

VAN APPELDOORN, L.J. \& FOCKEMA ANDREAE, S.J. 1939. De Groot's Inleidinge tot de Hollandsche rechts-geleertheid. 4de druk. Arnhem Quint : Bijleveldt. 


\section{A.L. Stander}

VAN DER WALT, C F C 1989 Enkele uitgangspunte vir 'n Suid-Afrikaanse ondersoek na beheer oor onbilike kontraksbedinge. Tydskrif vir Hedendaagse Romeins-Hollandse Reg, 52(1):81-93

VAN EIKEMA HOMMES, H.J. 1972. De elementaire grondbegrippen der rechtswetenschap Een juridische methodologie. Kluwer : Deventer.

VAN ZYL, D.H 1988. The significance of the concepts "justice" and "equity" in law and legal thought Somth African law' Journal, 105(2):272-290.

VISSER, C 1984. The principle of pacta servanda sumt in Roman and Roman-Dutch law, with specific reference to contracts in restraint of trade. South African low Journal, 101(4):641-655

\section{Lys van hofsake}

BK Tooling (Fdms) Bpk v Scope Precision Fingineering (Edms) Bpk 19791 SA 391 (A)

Cohen NO and others v Verwoerdhurg Town Council 1983 I SA 334 (A)

Drewtons (Pty) L.td v Carlic 19814 SA 305 (K)

North Vaal Mineral Co Lid v Lovasz 19613 SA 604 (T)

Marlin v Durhan Turf (lub and others 1942 AD 112

Printing \& Numerical Registering v Sampson (1875) LR 19 Eq 462462

Roffey v Caterall, Edwards \& Goudré 19774 SA $494(\mathrm{~N})$

Techni-Pak Sales (Pty) L.dd v Hall 19683 SA 231 (W)

Tuckers Land \& Development Corporation (Pty) Lid v Hovis 1980 I SA 645 (A)

Wells v SA Alumenite Co 1927 AD 69

Zuurbekom l.td v (mion Corporation l.td 1947 I SA 514 (A)

\section{Lys van wetgewing}

Insolvensiewer 24 van 1936

Wet op Arbeidsverhoudinge 28 van 1956

Wet op Kredicrooreenkom.ste 75 van 1980

Wet op Skadelike Sakepraktyke 71 van 1988

Wet op Strafbedinge 15 van 1962 